types of yeasts were isolated; these have not been fully identified, but none is a Schizo-saccharomycete.

As it is possible that the growth of bacteria and yeasts may inhibit the growth of selenomonads, single-cell culture methods were adopted. By micro-manipulation, four different morphological stages of Selenomonas ruminantium were transferred to each of the following media : potato dextrose agar, the same with addition of 20 per cent dextrose, synthetic medium with 2 per cent and 20 per cent dextrose added, potato dextrose agar with rumen filtrate (1: I) added. No growth whatever occurred after these transfers; indeed, contact with these media inhibited motility at once.

In addition to the media mentioned above, many others, inoculated with fresh motile selenomonad suspension and incubated aerobically, anaerobically, in carbon dioxide atmospheres, at low temperatures and high temperatures have been used without success.

The inferences from our culture studies are (1) Selenomonas ruminantium did not grow ; (2) if Schizosaccharomycetes had been present, they would have been observed.

Hence we believe that the predominant organism of the rumen is not a Schizo-saccharomycete. Further, we have found no evidence of Schizo-saccharomycetes in the rumen of sheep in Great Britain. We suggest that the term Schizo-saccharomyces ovis, as applied to the organisms in question, is misleading and should be discontinued.

$\begin{array}{cl}\text { Low Temperature Research } & \text { M. Ingram } \\ \text { Cambridge. } & \text { C. A. MoGadion, }\end{array}$

Institute of Animal Pathology, Cambridge. May 25.

2 MoGaughey, C. A., and Sellers, K. C., Nature, 161, 1014 (1948).

Quin, J. I., Onderstepoort J. Vet. Sei., 18, 91 (1943).

- Woodcook, H. M., and Lapage, G., Quart. J. Micr. Sci., 59, 431 (1943).

- Ledingham, quoted by Woodcock and Lapage (see ref. 3).

\section{British Folliculinidæ (Ciliata, Heterotricha)}

SINOE February 1947, I have had the opportunity of making an intensive search for Folliculinids at Plymouth, where I found four species, and at Cullercoats where five species were discovered. Except for Folliculina (Folliculinopsis?) ampulla, no record of Folliculinid species existed at these two marine laboratories. Besides the six species already recorded by me for Great Britain ${ }^{1}$, a seventh species, Folliculinopsis (Metafolliculina) andrewsi (Hadzi), found by me both at Plymouth and at Cullercoats, should now be added to the list of British species.

The species recorded by me are: F. producta, $F$. andrewsi, $F$. viridis and $F$. elegans from Plymouth (list and specimens with Director, Plymouth Laboratory), and $F$. producta, $F$. andrewsi, $F$. viridis, $F$. elegans and $F$. simplex from Cullercoats (list with Director, Dove Laboratory). The only other records are $F$. ampulla and $F$. elegans from Port Erin (Bruce ${ }^{2}$ ), and a single species, $F$. viridis, from Swansee (Fowell ${ }^{3}$ ). The finding of Folliculinopsis (Metafolliculina) andrewsi (Hadzi) is the first record of the species on the east side of the Atlantic (the species being common around Woods Hole, United States), as well as a first record for Great Britain.

I shall be grateful for information regarding British records of other species of Folliculinidæ, which workers in marine laboratories may come across, to enable me to include it in the systematic account well under way for publication.

My thanks are due to Wing-Commander F. S. Russell for allowing me a table at Plymouth in September 1947, and to Prof. A. D. Hobson for facilities for work in the Marine Laboratory at Cullercosts during 1946-47.

\section{Department of Zoology, \\ University, Lucknow. May 7.}

${ }^{1}$ Nature, 159, 502 (1947). Proc. Zool. Soc., 117 (2 and 3), 441 (1947). Bruce, Rep. Mar. Biol. Station, Port Erin, 48, 26 (1935). Fowell, Proc. Swansea Sci. and Field Nat. Soc., 2, 192 (1944). Nature,
160, 28 (1947).

\section{Number of Sperms Required for Fertilization}

MUCH has been done in recent years to determine the number of sperms which must be introduced by artificial insemination to maintain a normal rate of fertilization. There are, however, markedly divergent views as to the number of sperms normally present in the immediate vicinity of the eggs at fertilization. Such direct evidence as exists suggests very small numbers. Thus Hammond ${ }^{1}$ reports finding remarkably few in smears prepared from the fallopian tube of rabbits killed $10 \mathrm{hr}$. after coitus. Hammond and Walton ${ }^{2}$ examined the ovarian capsules of ferrets at 3-36 hr. after coitus, and counted 1,600 sperms in one ferret and 0-75 sperms in six others. The number of sperms in the tubes of rats were observed by Blandau and Moneys to increase during the hour after coitus to a maximum of about 200 .

On the other hand, it is a widely held theory that the eggs of many species of mammals must be freed from the surrounding mass of follicle cells, by means of hyaluronidase, before sperm penetration can take place, and there is a strong implication that a large aggregation of sperms is necessary to assure an adequate concentration of hyaluronidase. Pincus and Enzmann ${ }^{4}$ stated that at least 20,000 sperms/c.mm. are required for follicle cell dispersal and fertilization in vitro, and Pincus ${ }^{5}$ suggests that thw may also be the case in vivo. Kurzrok, Leonard and Conraa concluded from their studies that an accumulation of about 20 million sperms would be needed in the vicinity of the human egg in vivo.

It has been shown, however, that in the rat de. nudation of the egg is not a prerequisite of fertiliza. tion ${ }^{7,8}$. This would appear to remove the principal reason for supposing that large numbers of sperms are necessarily involved at fertilization. Further information on this matter has now been obtained.

When rabbits are artificially inseminated with $0 \cdot 5-1 \cdot 0 \times 10^{6}$ sperms and killed 12-15 hr. later, the eggs are frequently recovered in apparently intact masses of cumulus cells. Nevertheless, a proportion of the eggs show evidence of sperm penetration, and at $15 \mathrm{hr}$. the pronuclei can be discerned by means of the phase-contrast microscope. This confirms the observations previously recorded for the rat.

Attempts were made to count the number of sperms in the washings from the tubes of rabbits inseminated with about $1.0 \times 10^{8}$ sperms. Accurate assessment is very difficult owing to the relatively large volume of fluid required for thorough washing; but it was estimated that about 2,000-4,000 sperms were present throughout the length of a single tube. The number in the immediate vicinity of the eggs 